\title{
Using fish assemblages in different habitats to develop a management plan for the Upper Essequibo Conservation Concession, Guyana
}

\author{
Philip Wesley Willink ${ }^{1,3,4}$, Eustace Alexander ${ }^{2}$ \& Christopher Campbell Jones ${ }^{I}$ \\ ${ }^{1}$ The Field Museum, 1400 South Lake Shore Drive, Chicago, IL, 60605, USA \\ ${ }^{2}$ Conservation International - Guyana, 266 Forshaw Street, Queenstown, Georgetown, Guyana \\ ${ }^{3} J o h n$ G. Shedd Aquarium, Daniel P. Haerther Center for Conservation and Research, \\ 1200 South Lake Shore Drive, Chicago, IL, 60605, USA \\ ${ }^{4}$ Corresponding author: Philip Wesley Willink, e-mail: pwillink@sheddaquarium.org
}

WILLINK, P.W., ALEXANDER, E. \& JONES, C.C. Using fish assemblages in different habitats to develop a management plan for the Upper Essequibo Conservation Concession, Guyana. Biota Neotrop. 13(4): http:// www.biotaneotropica.org.br/v13n4/en/abstract?inventory+bn02713042013

Abstract: The Upper Essequibo Conservation Concession is a reserve in central-eastern Guyana managed by Conservation International. The site is uninhabited by people and poorly studied. The first scientific fish survey was in 2007 in conjunction with the filming of the BBC nature documentary Lost Land of the Jaguar. Aquatic habitats were primarily flowing water, ranging from the main channel of the Essequibo River to small forest creeks. Ponds and seasonally flooded forests were uncommon. Large predatory fishes were abundant in the Essequibo River. Fishes tolerant of low oxygen levels were common in flooded forests and small forest creeks. There was zero similarity between the fish assemblages of the Essequibo River and flooded forests / small forest creeks. The rest of the habitats and fish assemblages formed a continuum between these extremes. Imminent threats to the Upper Essequibo Conservation Concession include logging, mining, and over-fishing. Because of the heterogeneous distribution of fish assemblages, and because each threat will differentially affect different habitats, a two-pronged approach focusing on the ends of the habitat / fish assemblage continuum should be implemented in order to conserve the entire fish biodiversity of the Upper Essequibo Conservation Concession. Keywords: aquatic continuum, flooded forests, nature documentary, rapid assessment, fish.

WILLINK, P.W., ALEXANDER, E. \& JONES, C.C. Utilizando comunidades de peces en diferentes hábitats para desarrollar un plan de manejo para la Upper Essequibo Conservation Concession, Guyana. Biota Neotrop. 13(4): http://www.biotaneotropica.org.br/v13n4/pt/abstract?inventory+bn02713042013

Resumen: La Upper Essequibo Conservation Concession es una reserva en Guyana centro-oriental, administrada por Conservation International. El sitio está deshabitada por personas y mal estudiado. El primer estudio científico de peces fue en 2007 junto con la filmación del BBC documental naturaleza Lost Land of the Jaguar. Hábitats acuáticos fueron el canal principal del Río Essequibo a quebradas pequeñas del bosque. Lagos pequeños y bosques inundados estacionalmente eran infrecuentes. Grandes peces depredadores abundaban en el Río Essequibo. Peces tolerantes con bajos niveles de oxígeno eran comunes en quebradas pequeñas del bosque y bosques inundados. Hubo cero similitud entre las comunidades de peces del Río Essequibo y bosques inundados / quebradas pequeñas del bosque. El resto de los hábitats y comunidades de peces forma un continuum entre estos extremos. Las amenazas inminentes a la Upper Essequibo Conservation Concession incluyen deforestación, la minería y sobrepesca. Debido a la distribución heterogénea de comunidades de peces y porque cada amenaza diferencialmente afectarán a diferentes hábitats, un enfoque doble centrándose en los extremos del hábitat / comunidades de peces continuum debe aplicarse con el fin de conservar la biodiversidad de peces entero de la Upper Essequibo Conservation Concession.

Palavras clave: continuum acuático, bosques inundados, documental de naturaleza, evaluación rápida, peces. 


\section{Introduction}

Improving scientific information from conservation sites is crucial for guiding policy and management decisions. Scientific information can also be used to highlight the biological importance of sites, attract funding to support management, and demonstrate existing opportunities for biodiversity conservation. An example is the Upper Essequibo Conservation Concession (UECC) managed by Conservation International - Guyana.

The UECC - a High Biodiversity Wilderness Area of the Guianas Region located within the State's Forestry Zone of Guyana - is within a region designated to be important for conservation at a Priority Setting Workshop held in Suriname (Conservation International 2003). In order to safe-guard this site from the potential pressures associated with economic development until national protective legislation is enacted, Conservation International has been granted a conservation concession by the Government of Guyana. In essence, Conservation International leases forestry rights, but does not actually $\log$ the concession. This allows the site to be managed for biodiversity conservation while, at the same time, principal resource owners and stakeholders are compensated for lost economic opportunities.

However, despite the natural beauty of the pristine area, little was known about the region's biodiversity. The situation changed when the British Broadcasting Corporation (BBC) Natural History Unit became interested in the UECC not only because of its pristine state, biodiversity, and remote locality, but also by its concept and the fact that the site is in one of the few remaining unstudied areas of the Guiana Shield. Conservation International - Guyana, on the other hand, required baseline scientific data and the international promotion of the UECC and its concept. This led to a collaboration between the two organizations that allowed the UECC to be part of the BBC wildlife series known as Lost Land of the Jaguar (AKA Expedition Guyana or Lost World: Land of the Giants). A major spinoff of this collaboration was a demonstration of the new role that can be played by international media in facilitating the improvement of global knowledge on biodiversity. And it provided an opportunity to conduct a scientific survey of the aquatic habitats within the UECC.

Some of Guyana's fishes have been the subject of scientific investigation (Lasso et al. 2008). For example, Eigenmann (1912), Mol (2002), Hardman et al. (2002), Watkins et al. (2005), and Lasso et al. (2008) studied fishes primarily along the Rupununi River and lower and middle sections of the Essequibo River, but the upper areas are not well known. There remains a great deal of uncertainty regarding the total number of fish species existing in Guyana. Prior to this survey, it had been estimated that Guyana has over 700 species of fishes, more than 400 of which are recorded for the Iwokrama Forest alone (Watkins et al. 2005). Since many areas in the country are yet to be studied it is believed that the number of fish species in Guyana could be higher. There are several reasons for this paucity of data: limited national capacity, inaccessibility, high travel costs, hostile terrain, and treacherous cataracts in the upper reaches of most waterways being the most significant. The most pristine areas with the highest biodiversity of the country often are the most difficult to reach.

There are only a few national parks or reserves in Guyana, and none are located in the upper Essequibo River watershed. This ichthyological survey was the first to be conducted in the UECC. Therefore the data presented here is not only an improvement on the knowledge of fishes in the Essequibo River, but for Guyana as a whole.

\section{Description of study site}

The UECC occupies approximately 81,000 hectares of intact tropical rainforest straddling the Essequibo River just south of latitude four degrees North in the North Rupununi Region of Guyana (Figure 1). The terrain is gently sloping to hilly with elevations ranging between 90 meters to approximately 260 meters above sea level. The northern section of the site is relatively flatter and lower than the southern edge; consequently the North tends to be swampier than the South. The Essequibo River is the principal drainage channel with secondary drainage provided by Cocoa, Smyths, and Pouice creeks and another unnamed creek at the south-eastern boundary. These main waterways are augmented by an abundance of smaller tributaries which complement the drainage system and contribute to seasonal flooding. Because of the remote location and negligible human impacts, the UECC may serve as refugia for many aquatic species.

Except for timber inventories, a non-timber floristic survey, and a few qualitative faunal observations, the biodiversity of the site remains poorly understood. Observations during this expedition included 19 species of bats, 16 species of amphibians, and significant

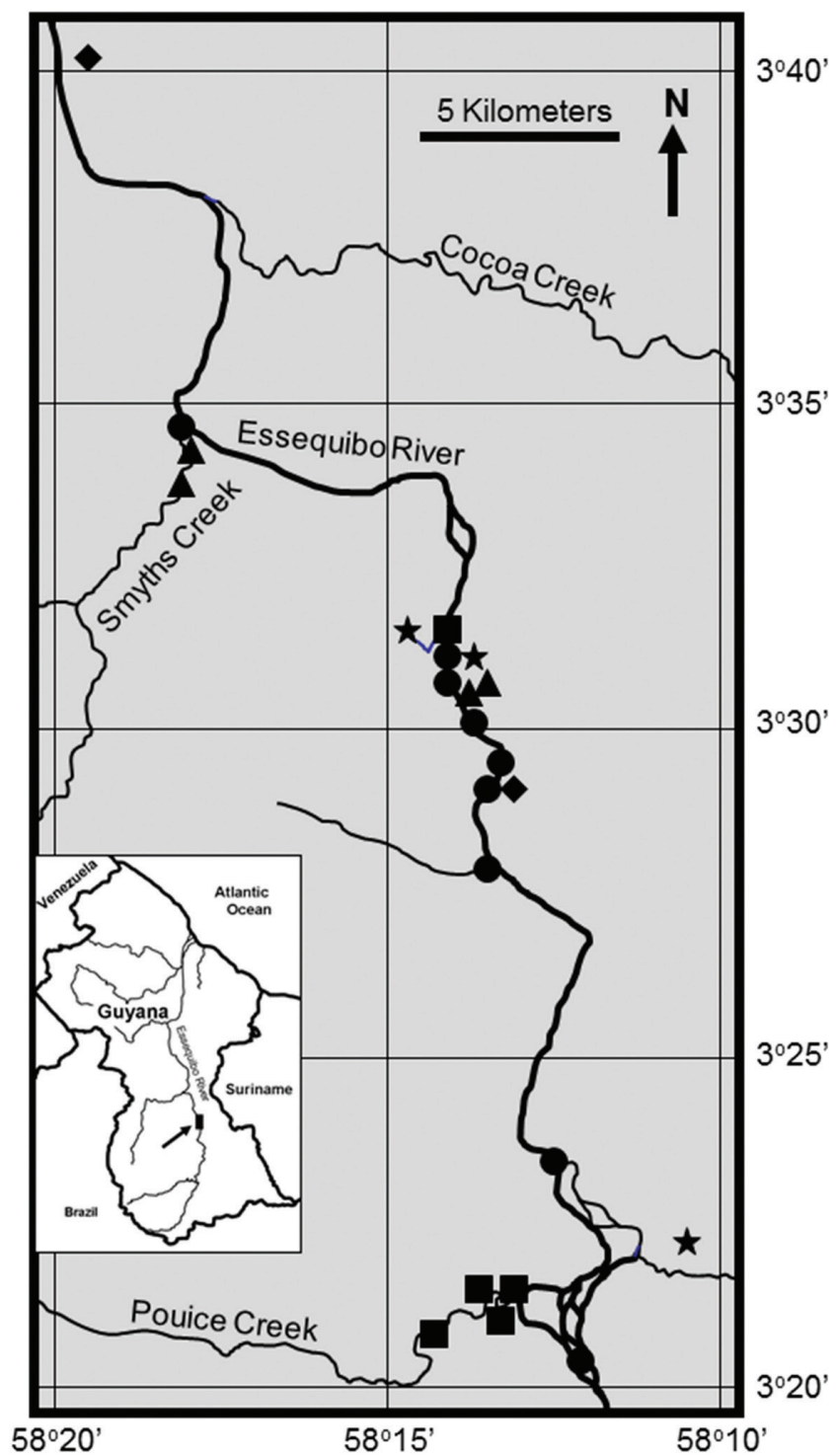

Figure 1. Map of Upper Essequibo Conservation Concession showing sampling stations and their habitat. Larger river = circle, Medium river - sand $=$ square, Medium river detritus - triangle, Small forest creek $=$ star, Flooded forest $=$ diamond . 
populations of tarantulas (Theraphosa blondi (Latreille 1804)), giant armadillo (Priodontes maximus (Kerr 1792)), giant otter (Pteronura brasiliensis (Gmelin 1788)), black caiman (Melanosucher niger (Spix 1825)), and jaguar (Panthera onca (Linnaeus 1758)).

\section{Material and Methods}

The fishes of the UECC were surveyed between September 15 and 30,2007 . Specimens were collected using 5 meter $\times 1.5$ meter seines, 40 meter $\times 2$ meter and 10 meter $\times 2$ meter gillnets, Fyke nets, dipnets, as well as hook and line. Every available type of aquatic habitat in the accessible portions of the reserve was sampled. This resulted in 25 sampling stations scattered throughout various sub-basins (Figure 1).

Specimens were preserved in $4 \%$ formalin, rinsed in water, and then transferred to $70 \%$ ethanol for long-term storage. All identifications were made at The Field Museum, Chicago, Illinois, USA.

Aquatic habitats were divided into five categories based primarily on stream flow and composition of the basement material (bedrock, boulders, sand, mud, leaves, sticks, etc.) (Table 1). Each sampling station and its associated fishes were assigned to a habitat type.

A cluster analysis was conducted in STATISTICA 5.5 using shared and unshared species among habitats. The hierarchical tree was computed based on single linkage and Euclidean distances.

Comparisons between lists of species for each habitat were made using the Tripartite Similarity Index (TSI) (Tulloss 1997). This index uses three 'cost functions' to calculate the similarity between lists (shared taxa), dissimilarity between lists (unshared taxa), and difference in size between lists. The three 'cost functions' are multiplied together to yield a single value.

EstimateS 8.2.0 was used to estimate species richness (Colwell 2009). The Classic option was used to compute Chao1 and Chao2.

\section{Results}

A total of 109 species were recorded during the expedition (Appendix). The number of species per habitat generally reflected the amount of water or stream width (Table 2). The exception was Large River which had fewer species than stream width would have predicted. A similar pattern emerged for current, ranging from swift to none. Type of bottom sediment reflected current velocity.
No species were found in all five habitats. Five species were found in four habitats (Curimatopsis crypticus Vari 1982, Hemigrammus ocellifer (Steindachner 1882), Hyphessobrycon minor Durbin 1909, Moenkhausia colletti (Steindachner 1882), and Pyrrhulina stoli Boeseman 1953), nine species in three habitats, 26 species in two habitats, and 69 species in one habitat.

The cluster analysis revealed a continuum ranging from Large River to Medium River - Sand to Medium River - Detritus to Small Forest Creek to Flooded Forest (Figure 2). Large River was the habitat most distant from all the others, followed by Medium River - Sand. The remaining three habitats were more closely linked.

The Tripartite Similarity Indices (TSI) reflected the cluster analysis (Table 3). Large River was most similar to Medium River - Sand $($ TSI $=0.185)$, followed by Medium River - Detritus $(\mathrm{TSI}=0.076)$. There was no overlap in species between Large River and Small Forest Creek or Flooded Forest, yielding TSIs $=0$. Overall, the lowest TSIs were comparisons made between Large River and any other habitat.

The highest TSI was Medium River - Detritus versus Small Forest Creek $($ TSI $=0.469)$, followed by Medium River - Sand versus Medium River - Detritus (TSI $=0.460)$. Intermediate values were Flooded Forest versus Small Forest Creek $($ TSI $=0.356)$ and Flooded Forest versus Medium River - Detritus (TSI = 0.315).

Medium River - Sand and Large River combined account for $79.8 \%$ of the species total (Figure 3). With the addition of Small Forest Creek, the three habitats account for $92.7 \%$ (Chernoff et al. 2004).

The species accumulation "curve" shows an initial burst in collection of species, followed by a plateau, then a sustained increase in the number of species discovered, and finally another plateau near 109 (Figure 4). The portions of the "curve" with higher slopes correlate with the exploration of novel habitats.

For species richness, EstimateS calculated Chaol $=170.54$, which was greater than the Abundance-based Coverage Estimator. The Incidence-based Cover Estimator $=185.59$, which was greater than Chao2 (Colwell 2009).

\section{Discussion}

Baseline scientific data are necessary to make informed conservation and management decisions. This can be particularly challenging in many South American reserves that are difficult to

Table 1. General aquatic habitat characterization in the Upper Essequibo Conservation Concession.

\begin{tabular}{lllcc}
\hline \multicolumn{1}{c}{ Habitat } & \multicolumn{1}{c}{ Stream Width } & \multicolumn{1}{c}{ Bottom } & Current & $\begin{array}{c}\text { Number of Sampling } \\
\text { Stations }\end{array}$ \\
\hline Large River & 40-couple hundred meters & Boulders, bedrock, some sand & Swift to moderate & 10 \\
Medium River - Sand & $10-20$ meters & Sand & Moderate & 5 \\
Medium River - Detritus & $2-25$ meters & Detritus (leaves, sticks, mud) & Moderate & 5 \\
Small Forest Creek & $<2$ meters & Detritus (leaves, sticks, mud) & Slow & 3 \\
Flooded Forest & Not applicable & Detritus (leaves, sticks, mud) & None & 2 \\
\hline
\end{tabular}

Table 2. Number of fish species per habitat and number of unique fish species per habitat in the Upper Essequibo Conservation Concession.

\begin{tabular}{lccccc}
\hline \multicolumn{1}{c}{ Habitat } & $\begin{array}{c}\text { Number of } \\
\text { Species }\end{array}$ & $\begin{array}{c}\text { \%o of Total Number } \\
\text { of Species (\%) }\end{array}$ & $\begin{array}{c}\text { Number of } \\
\text { Unique Species }\end{array}$ & $\begin{array}{c}\text { \% Unique within } \\
\text { Habitat (\%) }\end{array}$ & $\begin{array}{c}\text { \% Unique of Total } \\
\text { Number of Species (\%) }\end{array}$ \\
\hline Large River & 43 & 39.5 & 32 & 74.4 & 29.4 \\
Medium River - Sand & 53 & 48.6 & 20 & 37.7 & 18.4 \\
Medium River - Detritus & 30 & 27.5 & 2 & 6.7 & 1.8 \\
Small Forest Creek & 26 & 23.9 & 10 & 38.5 & 9.2 \\
Flooded Forest & 16 & 14.7 & 5 & 31.3 & 4.6 \\
\hline
\end{tabular}




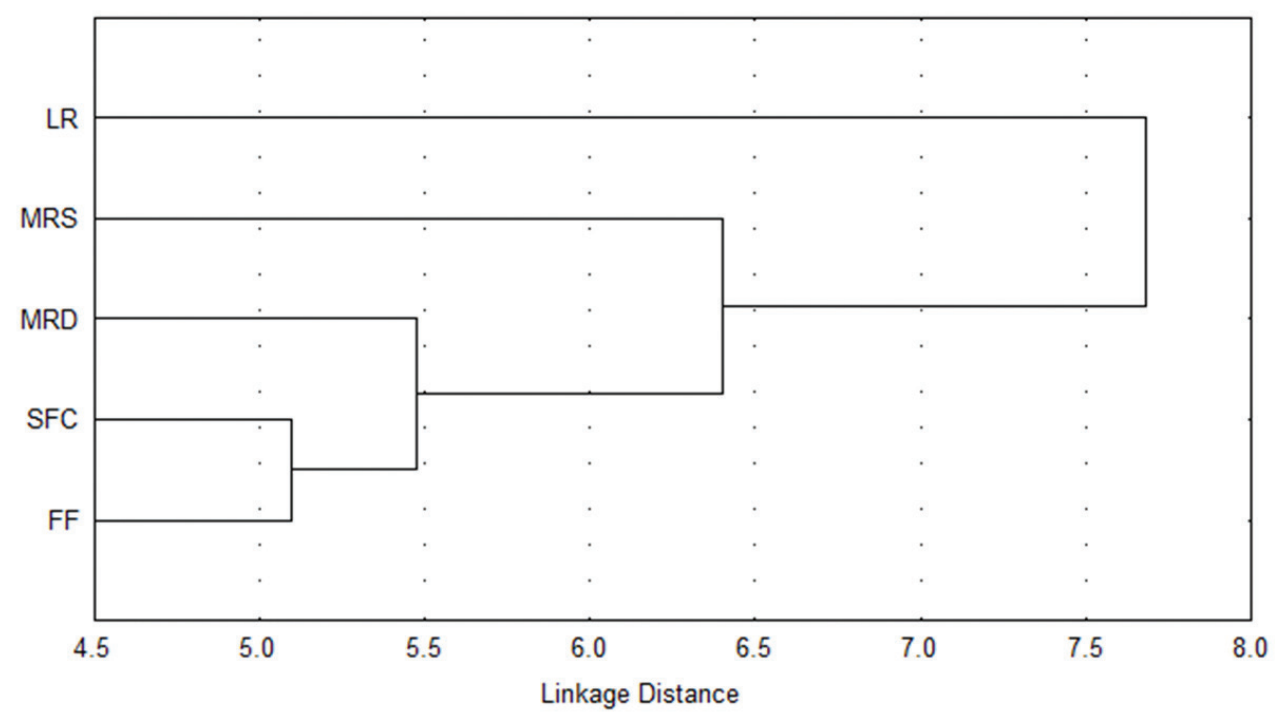

Figure 2. Cluster analysis using shared and unshared species to make comparisons among habitats in the Upper Essequibo Conservation Concession. $\mathrm{LR}=$ large river, $\mathrm{MRS}=$ medium river - sand, $\mathrm{MRD}=$ medium river - detritus, $\mathrm{SFC}=$ small forest creek, $\mathrm{FF}=$ flooded forest adjacent to seasonal pond.

Table 3. Number of shared species (upper right-hand corner) and Tripartite Similarity Indices (lower left-hand corner) among habitats in the Upper Essequibo Conservation Concession. $\mathrm{LR}=$ large river, $\mathrm{MRS}=$ medium river - sand, $\mathrm{MRD}=$ medium river - detritus, $\mathrm{SFC}=$ small forest creek, $\mathrm{FF}=$ flooded forest adjacent to seasonal pond.

\begin{tabular}{|c|c|c|c|c|c|}
\hline & LR & MRS & MRD & SFC & FF \\
\hline LR & ----- & 9 & 3 & 0 & 0 \\
\hline MRS & 0.185 & ----- & 21 & 12 & 9 \\
\hline MRD & 0.076 & 0.460 & ----- & 13 & 8 \\
\hline SFC & 0 & 0.270 & 0.469 & ----- & 8 \\
\hline FF & 0 & 0.215 & 0.315 & 0.356 & ----. \\
\hline
\end{tabular}

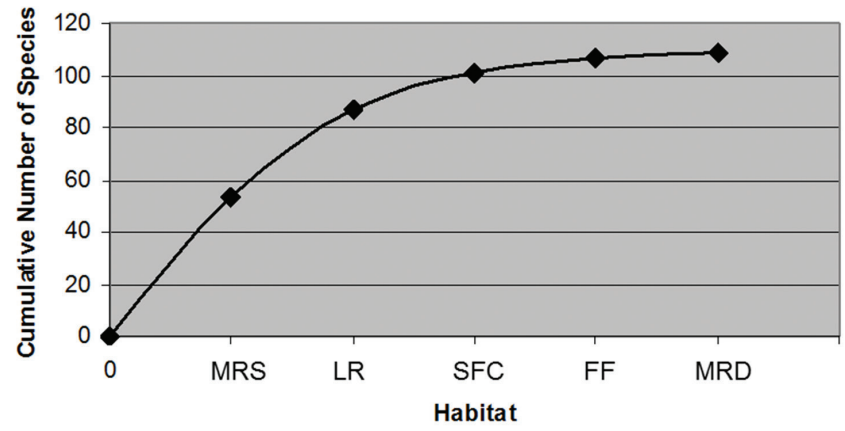

Figure 3. Cumulative number of species by habitat in the Upper Essequibo Conservation Concession. $\mathrm{LR}=$ large river, MRS $=$ medium river - sand, $\mathrm{MRD}=$ medium river - detritus, $\mathrm{SFC}=$ small forest creek, $\mathrm{FF}=$ flooded forest adjacent to seasonal pond.

reach and have never been systematically surveyed. But these areas are also incredibly important because they have not been affected by humans and constitute some of the last remaining vestiges of pristine landscape. Any data collected in these localities are valuable.

The expedition collected 109 species in the UECC. This is comparable to similar expeditions in the region, such as 112 species in the Coppename River (Mol et al. 2006) and 99 species in the Sipaliwini River (Willink et al. 2011). But there are undoubtedly more than 109 species within the reserve. EstimateS calculated 171-186

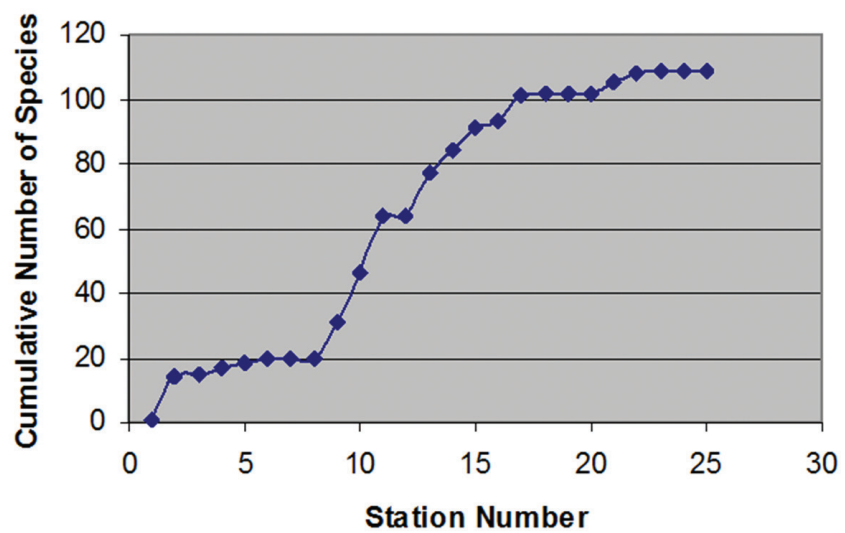

Figure 4. Accumulation of species collected in the Upper Essequibo Conservation Concession from September 15 to 30, 2007. Station numbers arranged chronologically.

species, and this seems like a reasonable estimate. We traveled as far as we could up Pouice Creek until our way was blocked by fallen trees and the stream was too shallow for our boat. The water level in Smyths Creek was high, making fish collecting difficult. And the entrance to Cocoa Creek was completely blocked by dense vegetation. Surveying other interior streams would require long, laborious treks through the jungle. The UECC should also be surveyed at different times of the year to account for seasonal effects. By the end of our expedition, we were catching largely the same species over and over 
again. Additional fieldwork is necessary to completely describe the fishes of the UECC, but we collected enough fishes to preliminarily characterize the primary habitats within the reserve and to begin making management recommendations.

Our data indicate that fish species are not distributed randomly or homogeneously across the landscape of the UECC. They are found in particular habitats, although the habitat requirements of some species are not as strict as those of other species. This has also been documented in the Rupununi watershed, with the most dramatic differences between savannah ponds and the main channel of the river (Lowe-McConnell 1964, de Souza et al. 2012).

For ease of analysis in our study, habitats were divided into discrete units, but this is rarely the case in nature. Rivers are known to be continuums (Horwitz 1978, Balon \& Stewart 1983) and that is apparent here. Flooded Forests and Small Forest Creeks are the initial forms of surface water in which fishes live. These flow into Medium River - Detritus that gradually transform into Medium River - Sand that empty into the Large River. The rate of this transformation can vary. For example, there are seasonal ponds within one kilometer of the Essequibo River, so there is a Flooded Forest flowing into a Small Forest Creek that empties directly into a Large River. The Medium River stage is absent, although the general continuum pattern is maintained.

The fishes reflect this continuum of habitats. There is a gradual change in species assemblages along the gradient, with no overlap between the extreme ends of the continuum (Large River versus Flooded Forest and Small Forest Creek) (Figure 2, Table 3). Both Silva et al. (2013) and Takahashi et al. (2013) found similar patterns in southern Brazilian streams. Upstream fish assemblages differed from downstream fish assemblages, and habitat played a role in constructing the pattern.

In the UECC, one end of the continuum, Flooded Forests and Small Forest Creeks, can change dramatically over the year. During the rainy season, water is available. But during the dry season, the habitats shrink in size, and sometimes disappear altogether. Fishes that can survive in several centimeters of water and are tolerant of low oxygen levels are most common. Body size also tends to be small. On the other end of the continuum, river levels fluctuate with the seasons in the Essequibo River, but water is always present. Current is usually faster. Oxygen is not typically a problem. Fish body size ranges from small to large. And there are more microhabitats to exploit.

When developing conservation plans, one often conducts a costbenefit analysis to determine how to save the most species / habitats for the least amount of money. According to Figure 3, focusing on Medium River - Sand and Large River will save the habitats for approximately $80 \%$ of the fish species within the reserve. These two habitats are usually adjacent to each other along the central riverine corridor, so this eliminates the need to trek long distances through the jungle, and further facilitates implementation of a management plan. However, this approach would sacrifice the ecologically distinct species in the Flooded Forests and Small Forest Creeks.

Instead, a management plan needs to address the entire gradient of habitats by taking into consideration the primary threats to the reserve. In this case, the two classes of threats are targeting each end of the continuum. The first is logging and gold mining. Although no logging is allowed in the reserve, the areas around the UECC are actively being divided into forestry concessions. Small-scale gold miners are actively prospecting the watershed. If surrounding areas are cleared of trees, an increase in erosion followed by sedimentation of headwaters would be expected. Small Forest Creeks will be severely affected. Depending upon the amount of erosion and the topography of the basin, the sediment could travel all the way to the Essequibo
River, affecting all aquatic habitats. The primary and most severe effect would be to Small Forest Creeks in the headwaters.

The second significant threat is over-fishing. This would target the Large River category because this is where the largest and most popular food fishes live. Large piranhas (e.g., Serrasalmus rhombeus (Linnaeus 1766)), pacus (e.g., Myleus pacu (Jardine 1841)), lukanani (Cichla ocellaris Bloch \& Schneider 1801) and large catfishes (e.g., Phractocephalus hemioliopterus (Bloch \& Schneider 1801)) are abundant in the Essequibo River. An abundance of large predatory fishes seems to be a common pattern for pristine regions of the Guiana Shield (Mol et al. 2006). Our guides delighted in catching them, and the entire expedition ate fish. But during the survey, it became more and more difficult to catch large fishes near the camp, forcing our guides to travel farther and farther to find food. A more detailed study is required to determine the productivity and fishery potential of the region, but our experience indicates that it could easily and rapidly be over-fished. No one lives in or near the UECC at the moment, but this is expected to change as Guyana develops.

A two-pronged management plan is recommended for the UECC, one part focusing on the headwaters (Small Forest Creek and Flooded Forest) and one part focusing on the main channel of the Essequibo River (Large River). By managing the two ends of the aquatic continuum, the intermediate gradient of habitats with their associated fishes has a greater probability of being conserved.

\section{Acknowledgments}

Stephen Backshall, Nicholas Allinson, Johnny Rogers, Dan Huertas, Edward Stafford, Amy Lathrop, Russel Mittermeier, Richard Rice, Mark Roberts, Eli, Nigel John, Fabian John, Dennis Alvin, Kevin, and various other fishermen helped us collect fishes. Stephen Greenwood, Timothy Martin, Daniel Huertas, Mandi Stark, Jonathan Young, Louise Ferguson, and Anne Backhouse made the BBC expedition possible. The Guyana Environmental Protection Agency provided permits. The directorate and management of Conservation International - Guyana facilitated the project.

\section{References}

BALON, E.K. \& STEWART, D.J. 1983. Fish assemblages in a river with unusual gradient (Luongo, Africa - Zaire system), reflections on river zonation, and description of another new species. Environ. Biol. Fish. 9(34):225-252. http://dx.doi.org/10.1007/BF00692373

CHERNOFF, B., WILLINK, P.W. \& MACHADO-ALLISON, A. 2004. Spatial partitioning of fishes in the Río Paraguay, Paraguay. Interciencia 29(4):183192.

COLWELL, R.K. 2009. EstimateS: Statistical estimation of species richness and shared species from samples. version 8.2. http://purl.oclc.org/ estimates

CONSERVATION INTERNATIONAL. 2003. Conservation priorities for the Guyana Shield. (O. Huber \& M.N. Foster, eds.). Conservation International, Center for Applied Biodiversity Science, Washington.

DE SOUZA, L.S., ARMBRUSTER, J.W. \& WERNEKE, D.C. 2012. The influence of the Rupununi portal on distribution of freshwater fish in the Rupununi district, Guyana. Cybium 36(1):31-43.

EIGENMANN, C.H. 1912. The freshwater fishes of British Guiana, including a study of the ecological groupings of species and the relation of the fauna of the plateau to that of the lowlands. Mem. Carn. Mus. 5(1):1-578.

HARDMAN, M., PAGE, L.M., SABAJ, M.H., ARMBRUSTER, J.W. \& KNOUFT J.H. 2002. A comparison of fish surveys made in 1908 and 1998 of the Potaro, Essequibo, Demerara, and coastal river drainages of Guyana. Ichthyol. Explor. Fres. 13(3):225-238.

HORWITZ, R.J. 1978. Temporal variability patterns and the distributional patterns of stream fishes. Eco. Monogr. 48(3):307-321. http://dx.doi. org $/ 10.2307 / 2937233$ 
LASSO, C.A., HERNANDEZ-ACEVEDO, J., ALEXANDER, E., SENARIS, J.C., MESA, L., SAMUDIO, H., MORA-DEY, J., MAGALHAES, C., SHUSHU, A., MAURUWANARU, E. \& SHONI R., 2008. Aquatic biota: fishes, decapod crustaceans and mollusks of the Upper Essequibo River (Konashen COCA), Southern Guyana. In A rapid biological assessment of the Konashen Community Owned Conservation Area, Southern Guyana (L.E. Alonso, J. McCullough, P. Naskrecki, E. Alexander \& H.E. Wright, eds.). Conservation International, Washington, p.43-54. RAP Bulletin of Biological Assessment 51.

LOWE-MCCONNELL, R.H. 1964. The fishes of the Rupununi savanna district of British Guiana, South America. J. Linn. Soc. (Zool.) 45(304):103-144. http://dx.doi.org/10.1111/j.1096-3642.1964.tb00490.x

MOL, J.H. 2002. A preliminary assessment of the fish fauna and water quality of the eastern Kanuku Mountains: lower Kwitaro River and Rewa River at Corona Falls. In A biodiversity assessment of the Eastern Kanuku Mountains, Lower Kwitaro River, Guyana (J.R. Montambault \& O. Missa, eds.). Conservation International, Washington, p.38-42. RAP Bulletin of Biological Assessment 26

MOL, J.H., WILLINK, P., CHERNOFF, B. \& COOPERMAN, M. 2006. Fishes of the Coppename River, Central Suriname Nature Reserve, Suriname. In A rapid biological assessment of the aquatic ecosystems of the Coppename River Basin, Suriname (L.E. Alonso \& H.J. Berrenstein,eds.) Conservation International, Washington, p.67-79. RAP Bulletin of Biological Assessment 39.
SILVA, J.F.M., RAIO, C.B., BERNARDINO, D.F.S. \& BENNEMANN, S.T. 2013. Longitudinal patterns of fish assemblages in mountain streams from tropical forest biome. Biota Neotrop. 13(3): http://www. biotaneotropica.org.br/v13n3/en/fullpaper?bn01213032013+en

TAKAHASHI, E.L.H., ROSA, F.R.T., LANGEANI, F. \& NAKAGHI, L.S.O. 2013. Spatial and seasonal patterns in fish assemblage in Córrego Rico, upper Paraná River basin. Neotrop. Ichthyol. 11(1):143-152. http:// dx.doi.org/10.1590/S1679-62252013000100017

TULLOSS, R.E. 1997. Assessment of similarity indices for undesirable properties and a new tripartite similarity index based on cost functions. In Mycology in sustainable development: expanding concepts, vanishing borders (M.E. Palm \& I.H. Chapela, eds.). Parkway Publishers, Boone, North Carolina, p.122-143.

WATKINS, G., SAUL, W., HOLM, E., WATSON, C., ARJOON, D. \& BICKNELL, J. 2005. The fish fauna of the Iwokrama Forest. P. Acad. Nat. Sci. Phil. 154(1):39-53. http://dx.doi.org/10.1635/00973157(2004)154\%5B0039:TFFOTI\%5D2.0.CO;2

WILLINK, P.W., WAN TONG YOU, K. \& PIQUE, M. 2011. Fishes of the Sipaliwini and Kutari rivers, Suriname. In A rapid biological assessment of the Kwamalasamutu region, Southwestern Suriname (B.J. O'Shea, L.E. Alonso \& T.H. Larsen, eds.). Conservation International, Washington, p.118-123. RAP Bulletin of Biological Assessment 63.

Received 03/08/2013

Revised 11/01/2013

Accepted 11/22/2013 
Willink, P.W. et al.

Appendix. List of species collected in the Upper Essequibo Conservation Concession and the habitats in which they were found.

\begin{tabular}{ccccc} 
Large River & $\begin{array}{c}\text { Medium } \\
\text { River - Sand }\end{array}$ & $\begin{array}{c}\text { Medium } \\
\text { River - Detritus }\end{array}$ & $\begin{array}{c}\text { Small Forest } \\
\text { Creek }\end{array}$ & Flooded Forest \\
\hline
\end{tabular}

\section{Osteoglossiformes}

\section{Osteoglossidae}

Osteoglossum bicirrhossum

\section{Clupeiformes}

\section{Engraulidae}

Anchoviella cf. jamesi

Characiformes

\section{Anostomidae}

Anostomus ternetzi

Leporinus maculatus

Leporinus nigrotaeniatus

Leporinus sp.

Characidae

Acestrorhynchus microlepis Agoniates halecinus

Aphyocharax erythrurus

Astyanax bimaculatus

Astyanax guianensis

Brycon falcatus

Brycon pesu

Bryconamericus hyphesson

Bryconops caudomaculatus

Chalceus macrolepidotus

Charax hemigrammus

Cynopotamus essequibensis

Hemigrammus analis

Hemigrammus aff. boesmani

Hemigrammus cylindricus

Hemigrammus erythrozonus

Hemigrammus ocellifer

Hemigrammus unilineatus

Heterocharax macrolepis

Hyphessobrycon minor

Hyphessobrycon rosaceus

Hyphessobrycon sp.

Jupiaba abramoides

Jupiaba polylepis

Moenkhausia chrysargyrea

Moenkhausia colletti

Moenkhausia cotinho

Moenkhausia hemigrammoides

Moenkhausia aff. icae

Moenkhausia aff. inrai

Moenkhausia aff. lepidura

Moenkhausia oligolepis

Myleus pacu

Phenacogaster microstictus

Poptella compressa

Pristobrycon calmoni

Serrasalmus rhombeus

Serrasalmus sp.

Tetragonopterus chalceus

$\mathrm{X}$

$\mathrm{X}$

$\mathrm{X}$

$\mathrm{X}$

$\mathrm{X}$

$\mathrm{X}$

$\mathrm{X}$

$-$

$-$

$-$

$\mathrm{X}$

$\mathrm{X}$

-

X

-

-

-

-

-

-

$-$

$-$

-

$-$

X

-

$-$

-

X

X
X

X

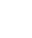

X

-

-

$-$

-

-

-

-

-

-

X

-

X

X

X

-

-

X

X

X

-

-

X

$\mathrm{X}$

X

-

X

-

-

-

-

-

X

- 
Appendix. Continued...

\begin{tabular}{|c|c|c|c|c|c|}
\hline & Large River & $\begin{array}{c}\text { Medium } \\
\text { River - Sand } \\
\end{array}$ & $\begin{array}{c}\text { Medium } \\
\text { River - Detritus }\end{array}$ & $\begin{array}{c}\text { Small Forest } \\
\text { Creek }\end{array}$ & Flooded Forest \\
\hline \multicolumn{6}{|l|}{ Chilodontidae } \\
\hline Caentropis maculatus & - & $\mathrm{X}$ & - & - & - \\
\hline Chilodus punctatus & - & $X$ & - & - & - \\
\hline \multicolumn{6}{|l|}{ Crenuchidae } \\
\hline Characidium pteroides & - & $\mathrm{X}$ & $\mathrm{X}$ & - & - \\
\hline Characidium sp. & $\mathrm{X}$ & - & - & - & - \\
\hline Characidium steindachneri & - & $\mathrm{X}$ & - & $\mathrm{X}$ & - \\
\hline Crenuchus spilurus & - & - & - & $X$ & - \\
\hline \multicolumn{6}{|l|}{ Curimatidae } \\
\hline Curimatopsis crypticus & - & $\mathrm{X}$ & $\mathrm{X}$ & $\mathrm{X}$ & $\mathrm{X}$ \\
\hline Cyphocharax spilurus & - & $\mathrm{X}$ & $\mathrm{X}$ & - & - \\
\hline Psectrogaster essequibensis & - & $\mathrm{X}$ & - & - & - \\
\hline \multicolumn{6}{|l|}{ Cynodontidae } \\
\hline Hydrolycus armatus & $\mathrm{X}$ & - & - & - & - \\
\hline \multicolumn{6}{|l|}{ Erythrinidae } \\
\hline Hoplias aimara & $\mathrm{X}$ & $\mathrm{X}$ & - & - & - \\
\hline Hoplias malabaricus & - & $\mathrm{X}$ & $\mathrm{X}$ & $\mathrm{X}$ & - \\
\hline \multicolumn{6}{|l|}{ Gasteropelicidae } \\
\hline Carnegiella strigata & - & - & $\mathrm{X}$ & $\mathrm{X}$ & $\mathrm{X}$ \\
\hline \multicolumn{6}{|l|}{ Hemiodontidae } \\
\hline Hemiodus sp. & $\mathrm{X}$ & - & - & - & - \\
\hline Hemiodus unimaculatus & $\mathrm{X}$ & - & - & - & - \\
\hline \multicolumn{6}{|l|}{ Lebiasinidae } \\
\hline Nannostomus marginatus & - & - & - & $\mathrm{X}$ & - \\
\hline Nannostomus unifasciatus & - & - & $X$ & - & $\mathrm{X}$ \\
\hline Pyrhulina stoli & - & $\mathrm{X}$ & $\mathrm{X}$ & $\mathrm{X}$ & $\mathrm{X}$ \\
\hline \multicolumn{6}{|l|}{ Parodontidae } \\
\hline Parodon guyanensis & $\mathrm{X}$ & - & - & - & - \\
\hline \multicolumn{6}{|l|}{ Siluriformes } \\
\hline \multicolumn{6}{|l|}{ Aspredinidae } \\
\hline Bunocephalus verrucosus & - & - & - & - & $\mathrm{X}$ \\
\hline \multicolumn{6}{|l|}{ Auchenipteridae } \\
\hline Ageneiosus sp. & $\mathrm{X}$ & - & - & - & - \\
\hline Auchenipterichthys coracoideus & $\mathrm{X}$ & - & - & - & - \\
\hline Tatia creutzbergi & - & - & - & $\mathrm{X}$ & - \\
\hline \multicolumn{6}{|l|}{ Callichthyidae } \\
\hline Corydoras melanistius & - & $\mathrm{X}$ & - & - & - \\
\hline \multicolumn{6}{|l|}{ Doradidae } \\
\hline Acanthodoras spinosissimus & $\mathrm{X}$ & - & - & - & - \\
\hline Amblydoras affinis & - & $\mathrm{X}$ & $\mathrm{X}$ & - & - \\
\hline Physopyxis ananas & - & $\mathrm{X}$ & $\mathrm{X}$ & - & - \\
\hline \multicolumn{6}{|l|}{ Heptapteridae } \\
\hline Chasmocranus brevior & $\mathrm{X}$ & - & - & - & - \\
\hline \multicolumn{6}{|l|}{ Loricariidae } \\
\hline Ctenoloricaria platystoma & $\mathrm{X}$ & - & - & - & - \\
\hline Hypoptopoma guianense & - & $\mathrm{X}$ & $\mathrm{X}$ & - & - \\
\hline Hypostomus taphorni & - & $\mathrm{X}$ & - & - & - \\
\hline Loricarichthys sp. & - & $X$ & - & - & - \\
\hline Loricarridae sp. & $\mathrm{X}$ & - & - & - & - \\
\hline Parotocinclus britskii & $\mathrm{X}$ & $\mathrm{X}$ & - & - & - \\
\hline Pseudancistrus nigrescens & $\mathrm{X}$ & - & - & - & - \\
\hline Rineloricaria platyura & $\mathrm{X}$ & - & - & - & - \\
\hline Rineloricaria sp. & - & $\mathrm{X}$ & - & - & - \\
\hline
\end{tabular}


Appendix. Continued...

\begin{tabular}{|c|c|c|c|c|c|}
\hline & Large River & $\begin{array}{c}\text { Medium } \\
\text { River - Sand }\end{array}$ & $\begin{array}{c}\text { Medium } \\
\text { River - Detritus }\end{array}$ & $\begin{array}{c}\text { Small Forest } \\
\text { Creek }\end{array}$ & Flooded Forest \\
\hline \multicolumn{6}{|l|}{ Pimelodidae } \\
\hline Leiarius marmoratus & $\mathrm{X}$ & - & - & - & - \\
\hline Megalonema platycephalum & - & $\mathrm{X}$ & - & - & - \\
\hline Phractocephalus hemioliopterus & $\mathrm{X}$ & - & - & - & - \\
\hline Pinirampus pirinampu & $\mathrm{X}$ & - & - & - & - \\
\hline Pseudoplatystoma fasciatum & $\mathrm{X}$ & - & - & - & - \\
\hline \multicolumn{6}{|l|}{ Pseudopimelodidae } \\
\hline Pseudopimelodus bufonius & $\mathrm{X}$ & - & - & - & - \\
\hline \multicolumn{6}{|l|}{ Trichomycteridae } \\
\hline Ochmacanthus flabelliferus & - & $\mathrm{X}$ & - & - & - \\
\hline Paracanthopoma parva & $X$ & - & - & - & - \\
\hline Vandellia beccarii & $X$ & - & - & - & - \\
\hline \multicolumn{6}{|l|}{ Gymnotiformes } \\
\hline \multicolumn{6}{|l|}{ Gymnotidae } \\
\hline Electrophorus electricus & $\mathrm{X}$ & - & - & - & - \\
\hline \multicolumn{6}{|l|}{ Hypopomidae } \\
\hline Brachyhypopomus brevirostris & - & - & - & $\mathrm{X}$ & - \\
\hline Brachyhypopomus pinnicaudatus & - & - & - & $\mathrm{X}$ & - \\
\hline Hypopygus lepturus & - & - & - & $\mathrm{X}$ & - \\
\hline \multicolumn{6}{|l|}{ Rhamphicthyidae } \\
\hline \multicolumn{6}{|l|}{ Beloniformes } \\
\hline \multicolumn{6}{|l|}{ Belonidae } \\
\hline Potamorrhaphis guianensis & $\mathrm{X}$ & $\mathrm{X}$ & $\mathrm{X}$ & - & - \\
\hline \multicolumn{6}{|l|}{ Cyprinodontiformes } \\
\hline \multicolumn{6}{|l|}{ Rivulidae } \\
\hline Rivulus sp. & - & - & - & $\mathrm{X}$ & - \\
\hline \multicolumn{6}{|l|}{ Synbranchiformes } \\
\hline \multicolumn{6}{|l|}{ Synbranchidae } \\
\hline Synbranchus marmoratus & - & $X$ & - & - & - \\
\hline \multicolumn{6}{|l|}{ Perciformes } \\
\hline \multicolumn{6}{|l|}{ Cichlidae } \\
\hline Apistogramma cf. ortmanni & - & - & $\mathrm{X}$ & - & - \\
\hline Apistogramma steindachneri & - & $X$ & $\mathrm{X}$ & $\mathrm{X}$ & - \\
\hline Biotodoma aff. cupido & - & $X$ & $\mathrm{X}$ & - & - \\
\hline Chaetobranchus flavescens & - & - & $\mathrm{X}$ & - & - \\
\hline Cichla ocellaris & $\mathrm{X}$ & - & - & - & - \\
\hline Cichlidae sp. & - & - & - & $\mathrm{X}$ & - \\
\hline Crenicichla alta & - & - & $\mathrm{X}$ & $\mathrm{X}$ & - \\
\hline Crenicichla wallacii & - & $\mathrm{X}$ & - & - & - \\
\hline Guianacara owroewefi & $X$ & $X$ & - & - & - \\
\hline Satanoperca leucosticta & - & $X$ & $\mathrm{X}$ & - & - \\
\hline
\end{tabular}

